\title{
Rhabdocline pseudotsugae.
}

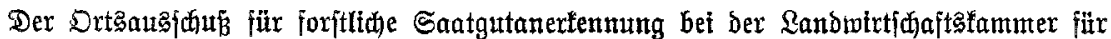

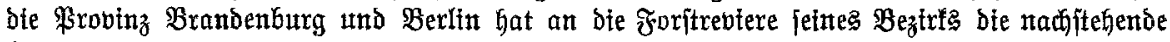

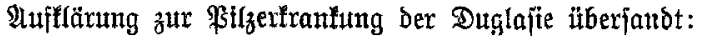

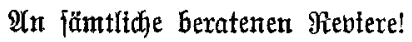

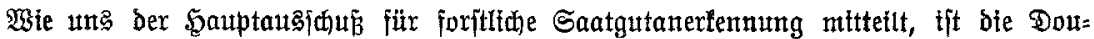

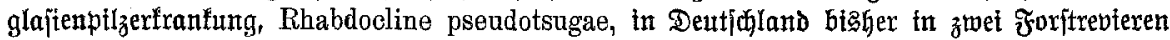

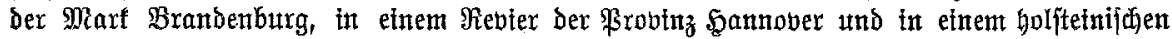

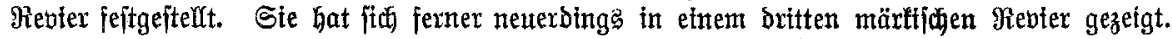

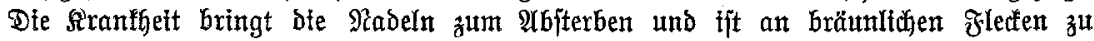

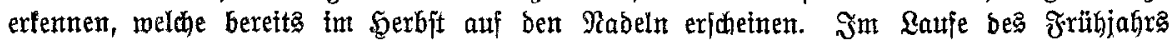

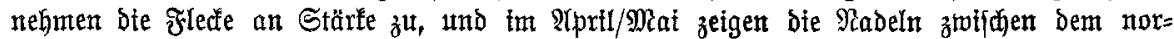

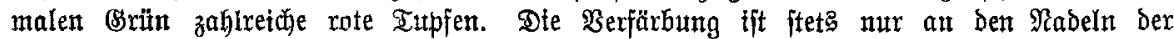
jüngiten Triebe zu benbachten, da bieje allein tnfettiona

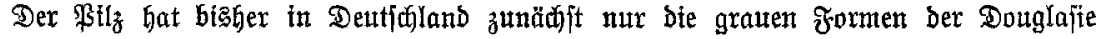
bejallent, wäbretto bie grïne Douglajte borexit veridunt geblteben ift.

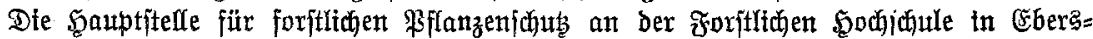

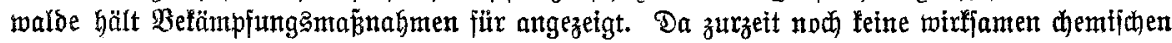
Betämpfungęmittel befannt find, wtro eine Eindämmung der Sirantfeit nur badurch zu er=

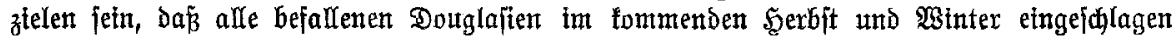

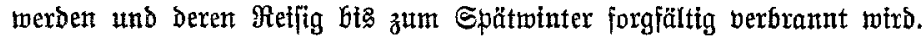

Whit teilen bieg ergebenjt ntt, empjeflen, Dte vorhandenten Douglajien auj etratige

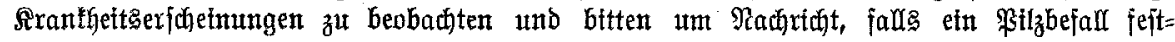
gefteldt ijt.

gez. Freth. b. Plettenberg.

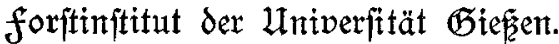

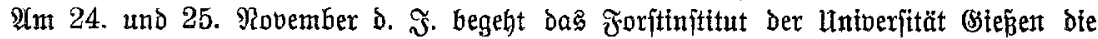

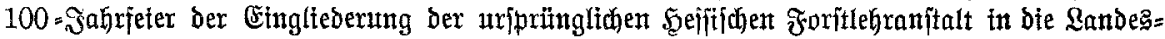

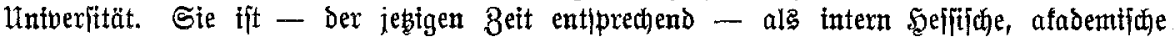
Feier gedadyt und wird mit einem Fortbildutgallehrgang für bte afabemifhen Forjtbeamten

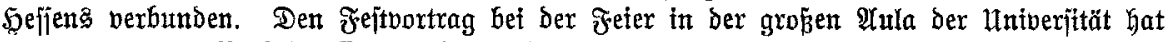

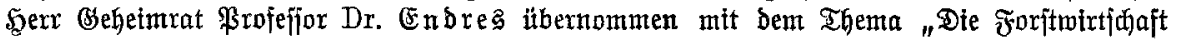

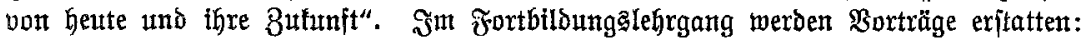

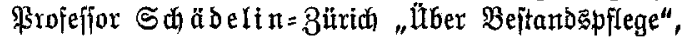

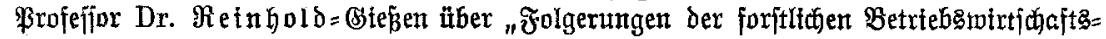

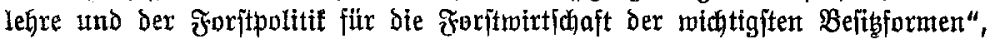

Brofeffor Dr. $̛$ Hnf W3albbătumen",

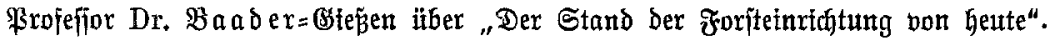

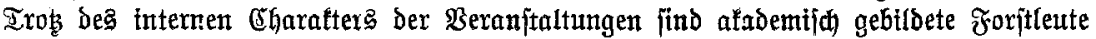

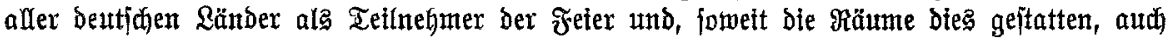

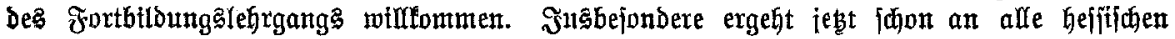

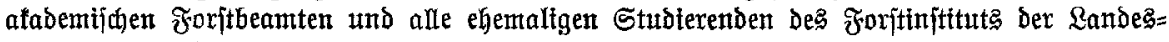
Univerfität Bstę̧en herzlliche Cinlabung zur Teilnahme.

\section{AFadentifhe Lachritht.}

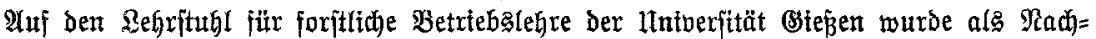

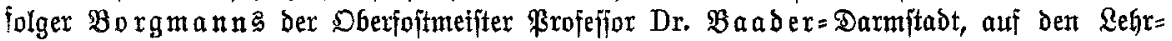

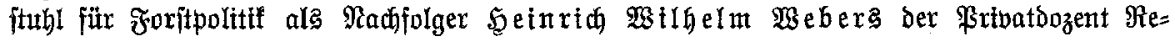

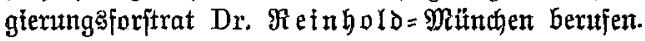

